Duthie, E. S. (1955). J. gen. Microbiol. 13, 383-393

\title{
The Action of Fibrinogen on certain Pathogenic Cocci
}

\author{
By E. S. DUTHIE \\ Royal South Hants Hospital, Southampton
}

\begin{abstract}
SUMMARY: The properties of the material responsible for the clumping reaction given by suspensions of coagulase-positive staphylococci when shaken in the presence of fibrinogen were examined and a possible mechanism is suggested for the reaction. Of other bacteria examined only streptococci of groups A, C and G absorbed fibrinogen, and of these relatively few gave clumping, though the cell material responsible for absorption was similar to that found in staphylococci. In staphylococci it is believed that a single substance is responsible for both absorption and clumping, and its properties suggest a peptide complex. The possible usefulness of coaguiasepositive cocci in the detection of minute amounts of fibrinogen is indicated.
\end{abstract}

In an earlier publication (Duthie, 1954) it was shown that the slide test for staphylococcal coagulase depended on substance on the staphylococcal cell wall which combined with the fibrinogen of certain animals, causing clumping of the bacteria when shaken. The reaction was in no way related to that produced in plasma by free coagulase, and the substance on the cell wall was named bound coagulase, although the alternative name 'clumping factor' was suggested. For reasons to be given later the latter name is now thought to be preferable. Clumping of the cells was found to be inhibited by staphylococcal antiserum prepared in either horses or rabbits, and this action of the antiserum was neutralized by material liberated from the cell wall of staphylococci early in autolysis. This crude material was antigenic and had properties, as judged by the antibody inhibition test, which were similar to those of clumping factor. It had no detectable action on fibrinogen. Further studies on clumping factor were clearly desirable and are reported in the present paper.

\section{METHODS}

Strains used. Unless otherwise stated, the experiments were carried out with the Newman strain of Staphylococcus aureus used previously. Cultures were grown in digest broth, agitated on a gramophone motor, washed and resuspended in saline to a standard density $\left(4 \times 10^{9}\right.$ cells $/ \mathrm{ml}$.). Since old cultures or suspensions sometimes gave indistinct clumping at low concentrations of fibrinogen, fresh suspensions were used when possible. Clumping at these low concentrations was often improved by boiling the cells for a few minutes or by adding a trace of bovine albumin.

Other pathogenic bacteria tested were grown in digest broth supplemented when necessary by human serum and glucose. Streptococci and pneumococci were grown in digest broth containing $2 \%(\mathrm{w} / \mathrm{v})$ peptone, $1 \%(\mathrm{w} / \mathrm{v})$ glucose and $3 \%(\mathrm{w} / \mathrm{v})$ sodium glycerophosphate. The pneumococcal cultures were supplemented by $0 \cdot 2 \%(\mathrm{w} / \mathrm{v})$ bovine albumin. Cells were spun down and re- 
suspended overnight in thiomersalate $0.05 \%(\mathrm{w} / \mathrm{v})$ after which they were washed, resuspended in saline and used. Streptococcal suspensions could be stored in saline containing chloramphenicol $0.01 \%(\mathrm{w} / \mathrm{v})$ for several weeks at $4^{\circ}$.

Plasma or fibrinogen titre. Standard cell suspension $(0.2 \mathrm{ml}$.) was added to $0.2 \mathrm{ml}$. vol. of increasing dilutions of fibrinogen or plasma in tubes $5.0 \times 0.8 \mathrm{~cm}$. The tubes were shaken vigorously for at least $4 \mathrm{~min}$. in a rack mounted horizontally on a 'Microid flask' shaker and were then examined with a hand lens in direct lighting and with a dark background. The degree of clumping was recorded as before (Duthie, 1954). Normal suspensions of the standard strain gave minimal clumping between 1 and $2.0 \times 10^{-7}(\mathrm{w} / \mathrm{v})$ human fibrinogen or at $1 / 20,000(v / v)$ fresh human plasma final concentrations. Suspensions giving less than minimal clumping or showing trace clumping when shaken in saline were discarded.

Titration of inhibitor or of antibody to bound coagulase. These titrations were carried out as in the previous paper (Duthie, 1954) except that the antiserum used was replaced by horse serum EX 1363 provided by the Wellcome Research Laboratories and which was assigned the arbitrary value of 300 units/ ml. Shaking was carried out until the tube receiving the $1 / 600$ dilution of this antiserum, i.e. $0.5 \mathrm{unit} / \mathrm{ml}$., gave faint clumping.

Absorption of antiserum. Volumes $(0 \cdot 1 \mathrm{ml}$.) of a five-times concentrated standard cell suspension $\left(2 \times 10^{10}\right.$ cells $/ \mathrm{ml}$.) were added to $0 \cdot 4 \mathrm{ml}$. volumes of increasing dilutions of antiserum ranging from 5 to $1 \mathrm{unit} / \mathrm{ml}$. and left in contact for $20 \mathrm{~min}$. on the bench, with occasional mixing. The cells were then removed by centrifuging and the supernatants compared with control antiserum to which the same volume of saline had been added. This was done by taking $\mathbf{0} \cdot 1 \mathrm{ml}$. volumes and adding $0.1 \mathrm{ml}$. of the standard suspension. After $20 \mathrm{~min}$. at room temperature $0.1 \mathrm{ml}$. of bovine fibrinogen $(0 \cdot 2 \%, \mathrm{w} / \mathrm{v})$ was added and the tubes shaken until the $5 \mathrm{unit} / \mathrm{ml}$. tubes absorbed with the suspension of Newman staphylococci gave minimal clumping. Comparison with tubes absorbed with other suspensions then showed greater or less clumping.

Absorption of fibrinogen. Volumes (0.1 ml.) of a five-times concentrated suspension of staphylococci were added to $\mathbf{0 . 4} \mathbf{~ m l}$. volumes of increasing dilutions of human fibrinogen, ranging usually between $0.002 \%$ and $0.0002 \%$ $(w / v)$ human fibrinogen. After a few minutes contact on the bench the cells were separated, $0.2 \mathrm{ml}$. volumes of the supernatants placed in fresh tubes and $0 \cdot 2 \mathrm{ml}$. volumes of standard suspension added. The tubes were usually shaken until minimal clumping appeared in the tube containing the least fibrinogen.

Absorption of fibrinogen on cells. Since cells coated with fibrinogen may not clump a further test was provided by washing cells, which had been in contact with fibrinogen, at least twice in saline and resuspending to the standard concentration. When $\mathbf{0 . 2} \mathrm{ml}$. of the standard suspension of coagulase-positive staphylococci was added to $0.2 \mathrm{ml}$. of these washed cells, clumping occurred when fibrinogen was present on their surfaces.

Enzyme preparations. The crystalline trypsin was that used by Duthie \& Lorenz (1949). Crystalline pepsin was a 1/60,000 National Formulary, U.S.A. preparation supplied by Armour Laboratories. Papain of unknown potency 
was supplied by the Nutritional Biochemical Corporation and was activated by the addition of NaCN. Lysozyme supplied by Armour Laboratories had a potency of $10^{6} \mathrm{unit} / \mathrm{g}$.

\section{RESULTS}

A comparison of the properties of a number of staphylococcal strains from various sources showed a good correlation between ability to absorb both antiserum and fibrinogen and the fibrinogen titre of the organisms (Table 1). Freshly isolated strains from pathological sources almost always possessed these qualities in high degree, old laboratory strains to a more variable and lesser extent, while albus strains from non-pathological sources did not possess them at all. Strains which failed to produce free coagulase as shown by the tube test were unable to absorb antiserum or fibrinogen and did not clump, though the converse was not necessarily true. Decrease in ability to absorb antiserum or fibrinogen or to clump at low concentrations of fibrinogen was not always accompanied by loss of toxic properties, since strain Wood 46 was the well-known producer of haemolysin, strain VL was a good producer of leucocidin and several strains such as 010 and Pusey produced large amounts of free coagulase in the presence of albumin. It should be noted that the Wood 46 strain, used to produce toxoid from which the antiserum used was derived, contained no surface antigen against this antibody, since it failed to absorb it.

Table 1. Comparison of absorption of antiserum, fibrinogen and the fibrinogen titre of different strains of staphylococci

Concentration before absorption

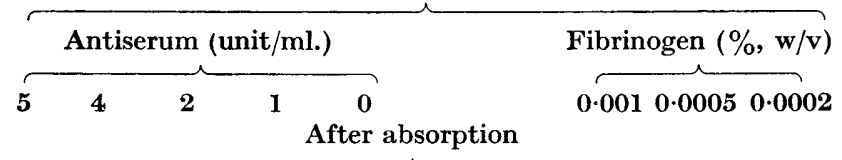

Inhibition of clumping by residual antiserum

$\begin{array}{llllll}\quad \text { Organism } & & & & & \\ \text { S. albus } & - & - & \text { tr. } & + & ++ \\ \text { Wood 46 } & - & - & \text { tr. } & + & ++ \\ \text { 010 } & - & - & \text { tr. } & + & ++ \\ \text { VL } & - & \text { tr. } & + & ++ & ++ \\ \text { Newman } & + & + \pm & ++ & ++ & ++ \\ \text { Saline control } & - & - & - & + & ++\end{array}$

Antibody
absorbed $\overbrace{}^{\begin{array}{c}\text { Clumping by } \\ \text { residual fibrinogen }\end{array}}$

$\begin{array}{cccc}\text { Nil } & ++ & ++ & ++ \\ \text { Nil } & ++ & ++ & ++ \\ \text { Nil } & ++ & ++ & ++ \\ \text { Some } & ++ & \pm & - \\ \text { Some } & + & \pm & - \\ \text { Nil } & ++ & ++ & ++\end{array}$

Free

Fibrinogen Fibrinogen coagulase absorbed titre production

$\begin{array}{ccc}\text { Nil } & \text { Nil } & - \\ \text { Nil } & \text { Nil } & \pm \\ \text { Nil } & \text { Nil } & ++ \\ \text { Some } & 10^{-5} & \pm \\ \text { Some } & 10^{-6} & ++ \\ \text { Nil } & & \end{array}$

$++=$ gross clumps $\quad+ \pm=$ clumps $\quad+=$ moderate clumps; $\pm=$ faint clumps $;$ tr. $=$ trace; $\quad-=$ zero result.

Stability of the clumping factor. Since it was uncertain whether or not the absorbing antigen on the cells was identical with clumping factor, parallel measurements were made of the three properties after heating at different $\mathrm{pH}$ values, treatment with certain enzyme preparations and finally extraction with fat solvents (Table 2). After treatment the cells were rewashed and suspended to the original volumes. It will be seen from Table 2 , which gives examples of these experiments with one strain of staphylococcus, that retention or loss of the three properties measured was well correlated. The clumping 
material was rapidly removed by pepsin and papain, somewhat more slowly by trypsin at $\mathrm{pH} \mathrm{9,} \mathrm{old} \mathrm{cultures} \mathrm{being} \mathrm{more} \mathrm{resistant} \mathrm{than} \mathrm{those} \mathrm{which} \mathrm{were}$ still multiplying before washing. No non-proteolytic enzymes were found which removed either the antigenic or fibrinogen-fixing material. There was no loss in $18 \mathrm{hr}$. at $\mathrm{pH} 11$ and $20^{\circ}$ but a marked loss at $37^{\circ}$ in the same time.

In general there was always some loss of the absorbing properties when the cells were heated for more than a few minutes at temperatures above $60^{\circ}$, and this loss increased with rise in temperature and exposure time. This was not always reflected in the clumping titre, since the cells became more unstable

Table 2. Changes in the properties of suspensions of the Newman strain following various treatments

Concentration before absorption

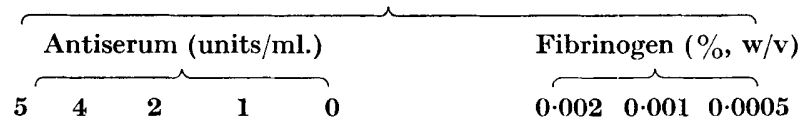

After absorption

Minimal concentration of

Effect on cell fibrinogen suspension normally giving ++ clumping

Treatment of suspensions

\begin{tabular}{|c|c|c|c|c|c|}
\hline \multicolumn{5}{|c|}{++ clumping } & loss \\
\hline- & - & - & \pm & ++ & Complete \\
\hline- & - & - & - & ++ & Complete \\
\hline - & - & - & \pm & ++ & Complete \\
\hline- & - & - & ++ & ++ & Complete \\
\hline tr. & + & ++ & ++ & ++ & Nil \\
\hline \pm & + & ++ & ++ & ++ & Nil \\
\hline
\end{tabular}

Clumping by

Fibrinogen

fibrinogen clumping

1. Papain $30 \mathrm{~min}$. pH 7

2. Pepsin 5 min. pH 2

3. Trypsin $10^{-3} 2 \mathrm{hr}$. pH 9.5

4. Held 2 hr. $37^{\circ} \mathrm{pH} 2$

5. Held 2 hr. $37^{\circ} \mathrm{pH} 9 \cdot 5$

6. Held 5 min. $60^{\circ} \mathrm{pH} 9 \cdot 5$

$\pm++++++$

$-\quad+\quad++++$

- tr. ++++

- tr. $t+++++$

- tr. $t \pm+t++$

$\pm++++++$

$\pm-t++++$

residual fibrinogen

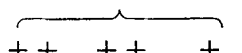

$\begin{array}{ll}t+t+ & + \\ +t+t & +\end{array}$

$+t+t$

$++$

$+$

Complete

Complete

Partial

Nil

Nil

Partial

Complete

Partial

Partial

Nil $+\quad \operatorname{tr}-$
$+ \pm-\quad$ Nil

$++\stackrel{+}{+}++$ Complete

$+\quad-\quad$ Nil

+ tr. - Partial

$+\quad-\quad$ Nil

$++t+ \pm$
Nil

Nil

Nil

10-7

10-7

Controls

clumped

$10-\tau$

Nil

10-7

$10-7$

$10-7$
11. Control cells

$++=$ gross clump $\quad+ \pm=$ clumps $; \quad+=$ moderate clumps $\quad \pm=$ faint clumps; tr. $=$ trace $; \quad-=$ zero result.

and tended to clump slightly in saline and to a higher titre in fibrinogen than did the original suspension. Storage of cell suspensions in saline usually resulted in a loss of all three properties with a progressive loss in stability of the cells in saline. All three properties were, however, stable in cells stored after heating in carbol-saline, although this had caused some initial loss. The cells displayed a remarkable resistance to extraction by fat solvents and there was little loss in their power to absorb either fibrinogen or antiserum following refluxing for $3 \mathrm{hr}$. in acetone. The resuspended cells were then slightly more unstable than before.

Antisera. These were readily produced by the intravenous or intracardiac injection of heat-killed staphylococci into rabbits or guinea-pigs. No anti- 
bodies were found when strains which failed to give clumping were injected, and this makes it difficult to account for the high titres in horses injected with toxoid from the Wood 46 strain since this strain does not clump and is apparently free from antigen. High titres were obtained after four to five injections of young cultures of the Newman strain killed by heating at $100^{\circ}$ for $5 \mathrm{~min}$. and adjusted to about $4 \times 10^{\circ} \mathrm{cell} / \mathrm{ml}$. As previously found (Duthie, 1954) the opalescent supernatant fluids of partially autolysed washed suspensions when absorbed on $\mathrm{AlPO}_{4}$ were antigenic; and when these supernatant fluids were brought to $\mathrm{pH} \mathbf{4 \cdot 6}$ and the deposits removed the fluids were equally active both as antigens and as inhibitors of antibody in the antibody inhibition test. Supernatant fluids from cells disintegrated by gentle autolysis with shaking in the cold or by vigorous shaking with ballotini were equally antigenic when absorbed on to $\mathrm{AlPO}_{4}$.

\section{Interaction of fibrinogen and cells}

Influence of $\mathrm{pH}$ value. While clumping of the cells occurred only above pH 5·1, absorption took place over the $\mathrm{pH}$ range 2-10. The fibrinogen showed loss in reactivity below $\mathrm{pH} 4.6$ and in consequence in Table 3 much higher fibrinogen concentrations were used below $\mathrm{pH} 4 \cdot 6$. It will be noted that some absorption occurred at all $\mathrm{pH}$ values, as shown by comparison with control solutions not absorbed and by the clumping of the washed and resuspended cells. Absorption increased up to $\mathrm{pH} 7$ and then remained maximal. Clumping of the cells began at pH $5 \cdot 1$ and was maximal at $\mathrm{pH} 5 \cdot 5$, the isoelectric point of fibrinogen, and above. Clumped cells were readily unclumped by bringing the $\mathrm{pH}$ below $5 \cdot 1$ and could be clumped once more by the addition of alkali.

\section{Table 3. The influence of change in $\mathrm{pH}$ on absorption of human fibrinogen} and on clumping of staphylococcal suspensions

Clumping of staphylococcal suspensions

\begin{tabular}{|c|c|c|c|c|c|c|c|}
\hline \multirow[b]{3}{*}{ pH value } & \multicolumn{3}{|c|}{ Unabsorbed fibrinogen } & \multicolumn{3}{|c|}{ Absorbed fibrinogen } & \multirow{3}{*}{$\begin{array}{l}\text { Clumping of cells } \\
\text { in fibrinogen } \\
0.02 \%(w / v)\end{array}$} \\
\hline & \multicolumn{6}{|c|}{ Concentration of fibrinogen absorbed $(\%, w / v)^{*}$} & \\
\hline & 0.02 & 0.01 & 0.0005 & 0.02 & 0.01 & 0.0005 & \\
\hline 2 & \pm & - & - & ++ & \pm & - & - \\
\hline 4 & + & - & - & ++ & + \pm & - & - \\
\hline
\end{tabular}

Concentration of fibrinogen absorbed $(\%, \mathrm{w} / \mathrm{v})^{*}$

$\begin{array}{cccccccc} & 0.002 & 0.001 & 0.0005 & 0.002 & 0.001 & 0 \cdot 0005 & \\ \mathbf{4 \cdot 6} & ++ & + \pm & + & ++ & + \pm & + & - \\ \mathbf{5} \cdot \mathbf{6} & + \pm & + & \pm & ++ & + \pm & + & \pm \\ \mathbf{6} \cdot \mathbf{0} & ++ & ++ & + & ++ & ++ & + \pm & ++ \\ \mathbf{7 \cdot 0} & ++ & + & - & ++ & ++ & + \pm & ++ \\ \mathbf{8} \cdot \mathbf{0} & + & \text { tr. } & - & ++ & ++ & + \pm & ++ \\ \mathbf{9 \cdot 7} & + & - & - & ++ & ++ & + \pm & ++\end{array}$

* Owing to the denaturation of fibrinogen at acid $\mathrm{pH}$, the concentration of fibrinogen necessary at $\mathrm{pH}$ values below 4.5 is about 10 times that for $\mathrm{pH}$ values above $4 \cdot 5$. 
Effect of $\mathrm{Na}$ and $\mathrm{Ca}$ ions. Absorption but not clumping was $\mathrm{Na}^{+}$dependent, trace clumping being present in $0.01 \mathrm{M}-\mathrm{NaCl}$ and moderate clumping in $0.015 \mathrm{M}-\mathrm{NaCl}$. Fibrinogen absorbed on coated cells was not removed by washing in distilled water or in dilute acetic acid. Cells washed in versene (ethylenediamine-tetra-acetic acid), which is a strong $\mathrm{Ca}^{++}$chelating agent, and subsequently shaken in fibrinogen containing $1 \%(\mathrm{w} / \mathrm{v})$ versene clumped normally, showing that neither absorption nor clumping was $\mathrm{Ca}^{++}$dependent. Clumping occurred in $20 \%$, but not in $30 \%$ urea, provided that sufficient $\mathrm{Na}$ ions were present. There was some inhibition of clumping in $3 \mathrm{M}-\mathrm{NaCl}$ but not in molar solutions.

Action of antiserum. Antiserum prevented not only absorption of fibrinogen by cells, but also clumping of cells to which fibrinogen was first added followed by antiserum before shaking. On the other hand, no evidence for the converse, i.e. inhibition of antiserum absorption by fibrinogen, was obtained. Thus cells were treated with fibrinogen to which antiserum was then added, both reagents being at limiting concentrations, and were compared with cells in antiserum only. On removing the cells an equivalent amount of fibrinogen was added to these control tubes. Titration of both lots of supernatants with cells did not reveal the difference that would have appeared if there had been impairment of antiserum absorption in the former mixtures. On another occasion antiserum was absorbed by fibrinogen-coated and by washed cells at $\mathrm{pH} 4 \cdot 8$. No difference was detected in the inhibitory power of the two lots of supernatants when compared at neutral $\mathrm{pH}$. Comparison at higher $\mathrm{pH}$ values was impossible because of the clumping of the fibrinogen-coated cells.

\section{Absorption of fibrinogen by streptococci and other particles}

Fibrinogen absorption by other bacteria. The following tests were made to determine whether organisms other than coagulase-positive staphylococci could either absorb or clump in human or bovine fibrinogen. Washed bacteria and yeast suspensions at a standard density were shaken in $0.02 \%(w / v)$ solutions of the two fibrinogens. When clumping was not seen the cells were washed twice and resuspended in saline, after which an equal volume of a standard suspension of coagulase-positive staphylococci was added and the suspensions shaken once more. Any clumping due to absorption of fibrinogen by the washed bacteria was then noted. Absorption tests were often made with three different concentrations of the fibrinogens and these were found to agree with the results already obtained. Of all bacteria and yeasts examined only streptococci of groups A, C and G absorbed human fibrinogen (Table 4). Neither of two freshly isolated strains of Streptococcus viridans from cases of subacute endocarditis nor any strains of $S$. faecalis were positive; seven strains of $S$. pneumoniae were all negative. None of the following organisms showed any ability to absorb fibrinogen or to clump in its presence: Staphylococcus albus, $S$. citreus, Micrococcus tetragenus, Neisseria gonorrhoeae, N. catarrhalis, $N$. meningitidis, Proteus vulgaris, Escherichia coli, Pseudomonas aeruginosa, Klebsiella pneumoniae and Candida albicans. 
There was some variation in the behaviour of those streptococci which had absorbed fibrinogen. Several gave fine immediate clumping with fibrinogen which was often more marked on washing and resuspension in saline. Others showed only slight or no clumping until the addition of the coagulase-positive staphylocci when gross floccules appeared instantly on shaking. These fibrinogen-coated streptococci clumped only on the addition of whole cells or particulate matter from crushed cells. They did not clump with thrombin or with free coagulase and prothrombin, nor did they clump with staphylococci in the presence of staphylococcal antiserum. All those streptococci which absorbed fibrinogen did so in amounts comparable to that absorbed by staphylococci, and absorption took place over the whole $\mathrm{pH}$ range from 2 to 10. Capsulated streptococci absorbed fibrinogen as readily as did non-capsulated forms.

Table 4. Absorption of human fibrinogen by streptococci and clumping in saline

$\begin{array}{llllllllllll}\quad \text { Group } \quad \ldots & \text { A } & \text { B } & \text { C } & \text { D } & \text { E } & \text { F } & \text { G } & \text { H } & \text { L } & \text { M } & \text { N } \\ \text { Strains tested } & \mathbf{9} & \mathbf{9} & \mathbf{4} & \mathbf{3} & \mathbf{4} & \mathbf{2} & \mathbf{4} & \mathbf{2} & \mathbf{2} & \mathbf{2} & \mathbf{2} \\ \text { Strains clumping alone } & \mathbf{3} & \mathbf{0} & \mathbf{0} & \mathbf{0} & \mathbf{0} & \mathbf{0} & \mathbf{0} & \mathbf{0} & \mathbf{0} & \mathbf{0} & \mathbf{0} \\ \text { Strains clumping with } & \mathbf{9} & \mathbf{0} & \mathbf{4} & \mathbf{0} & \mathbf{0} & \mathbf{0} & \mathbf{3} & \mathbf{0} & \mathbf{0} & \mathbf{0} & \mathbf{0}\end{array}$

Particles. When suspensions of coagulase-positive staphylococci were used to test for the presence or absence of fibrinogen it was possible to show that fibrinogen was absorbed readily by particles of a number of materials, mainly various diatomaceous earths. The conditions for absorption were similar to those obtaining with staphylococci and streptococci inasmuch as it occurred over a wide range of $\mathrm{pH}$ values and was independent of the presence of $\mathrm{Na}^{+}$. It was clear that 'Super cel', 'Hyflo super cel', 'Filter cel' (Johns-Mandville), kieselguhr, kaolin and talc readily absorbed fibrinogen. When washed, the majority of the particles clumped readily when coagulase-positive staphylococci were added and the suspensions shaken. Like streptococci these fibrinogencoated particles failed to clump with thrombin or with free coagulase + prothrombin.

Tanned erythrocytes. Human erythrocytes were treated with tannic acid and coated with human fibrinogen following the method of Boyden (1951), except that they were resuspended in a saline phosphate buffer without the addition of serum. When $0.04 \mathrm{ml}$. of a $2.5 \%$ suspension of these fibrinogen-coated cells was added to $\mathbf{0 . 2} \mathrm{ml}$. amounts of increasing dilutions of the standard staphylococcal cell suspension and the tubes shaken for a few moments, it was found that there was good clumping at a dilution of $1 / 20$ corresponding to $2 \times 10^{8}$ cells $/ \mathrm{ml}$. It was hoped to use this technique and also to use fibrinogen-coated particles of a diatomaceous earth for the assay of the clumping material liberated from the staphylococcal cells; within limits set by the nature of the material this has been possible. Suspensions of $2 \times 10^{10}$ staphyloccocal cells were partially disintegrated by means of: $(a)$ shaking for up to $2 \mathrm{hr}$. with Ballotini beads; $(b)$ treatment for $45 \mathrm{~min}$. with a Mullard low-frequency sonic 
disintegrator kindly lent by Dr D. D. Woods. Both methods decreased the optical density of the suspensions to about $20 \%$ of the original. Extraction of the cells with saline gave a material which was strongly inhibitory to antibody, but was only weakly active when mixed with either fibrinogen-coated red cells or particles. It was noted that the clumping titre for cells and particles fell with the amount of centrifuging that the preparation had received. Nevertheless, it was clear that these suspensions which contained particles barely visible under the microscope were able to inhibit antibody and to clump fibrinogen when suitably absorbed. They appeared to have no action on fibrinogen solutions. Numerous attempts to dissolve the particles or to remove the material from the surface of the cells by acids or alkalis were unsuccessful. Suspensions which were gently rocked at $4^{\circ}$ for prolonged periods released a material which was inhibitory to antiserum and antigenic when absorbed on $\mathrm{AlPO}_{4}$, but this had little or no clumping action on either coated cells or particles. In contrast to fibrinogen-coated streptococci and particles, the fibrinogen-coated erythrocytes were readily clumped by thrombin and by free coagulase + prothrombin mixtures.

Comparison of clumping by fibrinogen and agglutination by antibody. Because of a certain similarity between the clumping of staphylococci by fibrinogen and agglutination caused by antisera the following reaction was examined in some detail. When washed coagulase-positive staphylococci, coated with antisera, were shaken with uncoated staphylococci a fine clumping wasseen which resembled that given by human fibrinogen at $10^{-8}(\mathrm{w} / \mathrm{v})$. In practice the standard staphylococcal suspension was treated with antiserum at a final concentration of $30 \mathrm{units} / \mathrm{ml}$. for $10 \mathrm{~min}$. at $37^{\circ}$ and was then washed twice and resuspended to its original density. No clumping was seen on shaking, but only when an equal volume of untreated cells was added when clumping followed after a few minutes shaking. The reaction is similar to that described by Heidelberger \& Kabat (1934) when clumping of pneumococci was brought about by the addition not only of cells of the same group, but by the group specific polysaccharide. The reaction depends firstly on absorption of the specific antibody to the cell and secondly on the absorbed antibody uniting by free valencies with fresh sites on the non-sensitized cells, thus building up aggregates. It was therefore possible to determine the influence of certain ions on absorption of antibody and on the clumping of normal cells, and to compare this with similar findings when fibrinogen acted on staphylococci, streptococci and diatomaceous earth (Table 5).

The four types of reaction were essentially similar. Absorption of antibody or fibrinogen occurred over the whole range of $\mathrm{pH}$ values from 3 to 10 for antibody, and from $\mathbf{2}$ to $\mathbf{1 0}$ for fibrinogen, and was always independent of the $\mathrm{Na}^{+}$concentration. Clumping of the mixture of sensitized and non-sensitized cells was independent of $\mathrm{Ca}^{++}$, required a minimum of $0.01 \mathrm{M}-\mathrm{Na}^{+}$and took place between $\mathrm{pH} 4$ and 10. Clumping of fibrinogen-coated bacteria and particles also required a minimum of $0.01 \mathrm{M}-\mathrm{Na}$, was independent of $\mathrm{Ca}$ and occurred at $\mathrm{pH}$ values between $5 \cdot 1$ and 10.0. All reactions were reversible inasmuch as any alteration of the $\mathrm{pH}$ value to one outside either extreme or 
any lowering of the $\mathrm{Na}^{+}$below $0 \cdot 01 \mathrm{M}$, caused unclumping with further clumping when the former values were restored. This was most easily demonstrated with fibrinogen which was more stable to $\mathrm{pH}$ changes than was antibody.

Table 5. Comparison of conditions for absorption and clumping by fibrinogen and staphylococcal cell antibody

\begin{tabular}{|c|c|c|c|}
\hline Clumping systems & $\begin{array}{l}\text { pH range for } \\
\text { antibody or } \\
\text { fibrinogen }\end{array}$ & $\begin{array}{l}\mathrm{pH} \text { range for } \\
\text { clumping }\end{array}$ & Influence of ions \\
\hline $\begin{array}{l}\text { Antibody coated Staphylo- } \\
\text { coccus aureus+normal } S . \\
\text { aureus }\end{array}$ & $3 \cdot 0-10 \cdot 0$ & $4 \cdot 0-10 \cdot 0$ & $\begin{array}{l}\mathrm{Na}^{+} \text {not needed for } \\
\text { absorption but at } \\
\text { least } 0.01 \text { M-NaCl }\end{array}$ \\
\hline Fibrinogen $+S$. aureus & $2 \cdot 0-10 \cdot 0$ & $5 \cdot 1-10 \cdot 0$ & essential for clumping \\
\hline $\begin{array}{l}\text { Fibrinogen coated Strepto- } \\
\text { coccus haemolyticus }+ \text { Staphylo- } \\
\text { coccus aureus }\end{array}$ & $2 \cdot 0-10 \cdot 0$ & $5 \cdot 1-10 \cdot 0$ & $\begin{array}{l}\text { which was reversible } \\
\text { outside pH limits } \\
\text { given }\end{array}$ \\
\hline $\begin{array}{l}\text { Fibrinogen coated 'Super- } \\
\text { cel' }+S \text {. aureus }\end{array}$ & $2 \cdot 0-10 \cdot 0$ & $5 \cdot 1-10 \cdot 0$ & \\
\hline
\end{tabular}

\section{DISCUSSION}

Coagulase-positive staphylococci are distinguished from others by their ability to absorb fibrinogen, to clump, and to form a common antibody which inhibits this phenomenon. The remarkably good correlation observed between the three properties at all times and under all circumstances makes it likely that the same substance is responsible, although this cannot be proved conclusively because of failure to separate a soluble material from the cells. Since the absorption of fibrinogen and the clumping do not appear to be due to the action of an enzyme, it is proposed that the material responsible be called 'clumping factor' rather than bound coagulase as previously suggested. The marked stability of clumping factor is noteworthy; at pH 11 there is partial destruction in $24 \mathrm{hr}$. at $37^{\circ}$ but none at $20^{\circ}$, although treatment at this $\mathrm{pH}$ value usually destroys surface antigens in other bacteria. Clumping factor was resistant to boiling and was unaltered by acetone, ethanol or ether extraction. Autoclaving and treatment with certain proteolytic enzyme preparations destroyed it. It was recovered in a particulate form from the supernatant fluids of suspensions of cells disrupted mechanically. It should be noted that such supernatant fluids were active antigenically both by the antibody inhibition test and in producing antibody in animals; but their ability to induce clumping of fibrinogen-coated particles, of red cells, or of antibody-coated staphylococcal cells was limited. Clumping factor might well be a peptide complex, but until it can be obtained in a soluble form which can be demonstrated by a suitable test this cannot be verified.

The clumping of staphylococci by fibrinogen is now seen to occur in two stages. First, there is an absorption of fibrinogen by the cells similar to that found with certain streptococci and with certain inanimate particles, e.g. diatom skeletons. All these absorptions occur ver the range pH 2-11, in which fibrinogen is stable, and they are independent of ions. The second stage, 
clumping, begins at $\mathrm{pH} 5 \cdot 1$, is maximal at $\mathrm{pH} 5 \cdot 5$ the isoelectric point of fibrinogen, and continues up to $\mathrm{pH}$ 10. In this it resembles the clotting of fibrinogen by thrombin (Lorand, 1954). Since clumping is maximal at the isoelectric point of fibrinogen, i.e. when negatively-charged groups appear on the fibrinogen molecule it may be assumed that the fibrinogen first decreases the mutually repelling electrostatic forces on the staphylococci, as shown by the decrease in surface charge, and that free negatively-charged groups of the absorbed fibrinogen then unite with positively charged groups on other cells, thus giving aggregation. A similar explanation for serum agglutination was put forward by Heidelberger \& Kabat (1934).

To account for the factors involved in the clumping of staphylococci and of streptococci the following scheme can serve as a working hypothesis. Staphylococci may be thought of as having primary absorbing sites $\mathbf{A}$ and secondary binding sites B which only unite with fibrinogen suitably oriented by first being absorbed on the primary sites. The secondary sites $\mathbf{B}$ are presumably absent from streptococci of groups $\mathrm{A}, \mathrm{C}$ and $\mathrm{G}$ which can, however, form clumps when whole staphylococci or particles containing $\mathbf{B}$ sites are added to the fibrinogen-coated cells. When antiserum is added to normal staphylococcal cells both primary and secondary sites are blocked by antibody and the cells cannot absorb fibrinogen. When antiserum is added to fibrinogen-coated cells then the secondary sites B are blocked by antibody and the suspensions cannot clump when shaken. The hypothesis covers all the known facts but cannot be proved since it was found impossible to destroy one presumptive site only. From the nature of the experiments it would appear that a single substance is responsible, the sites being different groups.

One of the main uses of staphylococcal clumping factor lies in its ability to detect extremely small amounts of either normal or denatured fibrinogen of certain animals, in solution or when absorbed on particles. Pure human fibrinogen showed visible clumping at $1 \mathrm{mg}$./ 1 . and human plasma showed visible clumping at a dilution of $1 / 20,000$ when mixed and shaken with an equal volume of the standard bacterial suspension made slightly more sensitive by boiling for a few minutes. Allowing that this plasma contained between 0.2 and $0.4 \%(\mathrm{w} / \mathrm{v})$ fibrinogen this meant that each cell was clumped by as little as 12-24 molecules of fibrinogen. That most diatomaceous earths readily absorb fibrinogen was well known, but that this property is shared only by pathogenic staphylococci and groups A, C and G streptococci is more surprising. Absorption of fibrinogen by these bacteria is apparently due to the presence in all these organisms of a similar substance which is resistant to moderate heat (boiling but not autoclaving), to moderate $\mathrm{pH}$ changes ( $\mathrm{pH} \mathrm{2-11}$ ) and to extraction by lipid solvents. Since it was destroyed easily by proteolytic enzymes it is presumably a peptide complex. Bacteria which failed to absorb fibrinogen could not be made to do so by any chemical or physical means employed.

As mentioned earlier (Duthie, 1954), staphylococci of doubtful pathogenicity are found from time to time which produce free coagulase but fail to clump even in strong concentrations of fibrinogen or plasma. It has now been found 
that on several subcultures the majority of these strains give clumping though never in high titre. Similarly, strain variants have been found in cultures which give clumping but show no free coagulase either in tube or plate tests. Neither of these variants has yet been found in pathological lesions, and it may be assumed that either the conventional slide or the tube test is a good guide to pathogenicity in material recovered from lesions though not necessarily from body surfaces.

I wish to thank the Lister Institute of Preventive Medicine, London, for providing specimens of fibrinogen, the Wellcome Research Laboratories, Beckenham, Kent, for providing antiserum, and the National Collection of Type Cultures and various individual workers for providing the strains used. I am also grateful to Miss I. Campbell for helpful discussions, to Dr D. D. Woods for permitting me to use a Mullard Sonic Disintegrator and to Miss S. Isherwood and Miss J. Rowland for valuable technical assistance. The work was financed by a research grant from the South West Metropolitan Regional Hospital Board.

\section{REFERENCES}

Boyden, S. V. (1951). Adsorption of proteins on erythrocytes treated with tannic acid and subsequent haemagglutination by antiprotein sera. J. exp. Med. 93, 107.

Duthie, E. S. (1954). Evidence of two forms of staphylococcal coagulase. J. gen. Microbiol. 10, 427.

Duthie, E. S. \& Lorenz, L. (1949). Protease inhibitors: I. Assay and nature of serum antiprotease. Biochem. J. 44, 167.

Heidelberger, M. \& Kabat, E. A. (1934). Chemical studies on bacterial agglutination. I. A method. J. exp. Med. 60, 643.

Lorand, L. (1954). Interaction of thrombin and fibrinogen. Physiol. Rev. 34, 742.

(Received 2 May 1955) 